\title{
OZONE PRE-OXIDATION OF A TEXTILE INDUSTRY WASTEWATER FOR ACUTE TOXICITY REMOVAL
}

\author{
H. SELCUK ${ }^{1}$ \\ S. MERIC ${ }^{2^{*}}$
}

\author{
${ }^{1}$ Pamukkale University \\ Department of Environmental Engineering \\ Kinikli,Denizli, Turkey \\ ${ }^{2}$ Department of Civil Engineering \\ University of Salerno \\ 4084 Fisciano (SA), Italy
}

Received: 30/5/2005

Accepted: 15/2/2006 *to whom all correspondence should be addressed: e-mail: smeric@tin.it; msureyya@unisa.it

\begin{abstract}
In this work, pre-ozonation for degradation, decolourization and detoxicifying of a raw textile wastewater collected in a textile fininshing industry, Istanbul (Turkey) is investigated. Differing from the previous studies, a low ozone $\left(\mathrm{O}_{3}\right)$ flow rate $\left(9.6 \mathrm{mg} \mathrm{min}^{-1}\right)$ was applied at original $\mathrm{pH}$ of the wastewater. The effect of $\mathrm{pH}$ varying from 5 to 11 and the $\mathrm{H}_{2} \mathrm{O}_{2}$ dose of $600 \mathrm{mg} \mathrm{l}^{-1}$ on ozone oxidation were also investigated. The acute toxicity of raw and treated wastewater samples were measured using $24 \mathrm{~h}$ newborn Daphnia magna. COD, colour in APHA Pt-Co (platin-cobalt) unit and absorbance at 450,500 and $550 \mathrm{~nm}$ wave lengths which were coinciding the peak absorbance band of the raw wastewater were analyzed in treated samples.
\end{abstract}

A $60 \%$ of acute toxicity, $92 \%$ of and $50 \%$ of total COD removal were obtained at original $\mathrm{pH}$ of wastewater by applying ozone for $30 \mathrm{~min}$. Absorbed ozone dose was $105 \mathrm{mg} \mathrm{l}^{-1}$ with a ozone transfer rate of $3.5 \mathrm{mg} \mathrm{l}^{-1}$. Varying $\mathrm{pH}$ did not improve toxicity removal, however, soluble COD removal increased at 3 and $6 \%$ respectively for 9.0 and 11.0 values while colour removal increased $(7 \%)$ only at $11.0 \mathrm{pH}$. Adding $600 \mathrm{mg} \mathrm{I}^{-1}$ of $\mathrm{H}_{2} \mathrm{O}_{2}$ increased COD removal at $10 \%$ after 20 min oxidation. Colour removal increase was more significant in $\mathrm{O}_{3} / \mathrm{H}_{2} \mathrm{O}_{2}$ oxidation in parallel with the increase in absorbance kinetics.

All over results obtained this study are expected to contribute to control the textile industry wastewater pollution and to protect aquatic environment.

KEYWORDS: textile wastewater, pre-ozonation, ozone $/ \mathrm{H}_{2} \mathrm{O}_{2}$ advanced oxidation, pH effect, biodegradation, detoxification, colour removal, Daphnia magna

\section{INTRODUCTION}

Textile industry originates a complex wastewater containing various chemicals used in the process such as dyestuff, surface-active materials and textile additives. Many azo dyes which cause intensive colour in the wastewater [1-5] and textile industry effluent [6-8] have been found to mutagen/carcinogen/toxic to aquatic organisms. Many advanced oxidation processes (AOPs) such as photocatalytic oxidation [9], Fenton [8] and Photo-fenton oxidation [10] have been applied individually or combined with $\mathrm{UV}, \mathrm{H}_{2} \mathrm{O}_{2}$ oxidants to decolourize, detoxicify and degradate textile wastewater and dyes.

Ozone $\left(\mathrm{O}_{3}\right)$ oxidationas has been extensively studied to decolourise dyes [11] or preoxidation to enhance the biodegradability [12-14] or to reduce inert COD fractions [15] and toxicity removal $[8,9,16]$ and post treatment of textile industry wastewater [17].

Both molecular ozone and especially hydroxyl radical $\left(\mathrm{OH}^{\circ}\right)$ which is non selective oxidant forming decomposition of $\mathrm{O}_{3}$ as explained by eqs (1-2), play an important role for the oxidation of organics [18]: 
$\mathrm{O}_{3} \leftrightarrow \mathrm{O}+\mathrm{O}_{2}$

$\mathrm{O}+\mathrm{H}_{2} \mathrm{O} \leftrightarrow 2 \mathrm{OH}^{\bullet}$

These reactions occur simultaneously. The chromophor groups in textile dyes can be broken by ozone (directly or indirectly) forming smaller molecules resulting in colourless effluent [11]. The wastewater characteristics (i.e. pH, concentration of initiators, promoters and scavengers) play important role on the process efficiency, hence on the reaction kinetics. For instance, $\mathrm{O}_{3}$ decomposes readily to $\mathrm{OH}^{\bullet}$ radicals at high $\mathrm{pH}$ (11.012.0), while ozone reacts with $\mathrm{OH}^{-}$and produces hydroperoxide radicals according to eq. 3:

$\mathrm{O}_{3}+\mathrm{OH}^{-} \rightarrow \mathrm{HO}_{2} \cdot+\mathrm{O}_{2} \cdot \quad \mathrm{k}=70 \mathrm{M}^{-1} \mathrm{~s}^{-1}$

When ozone is used with $\mathrm{H}_{2} \mathrm{O}_{2}$ (weak acid), here ozone reacts both with $\mathrm{H}_{2} \mathrm{O}_{2}$ and $\mathrm{HO}_{2}^{-}$ which occurs much faster than $\mathrm{H}_{2} \mathrm{O}_{2}$. Thus, the reaction with $\mathrm{H}_{2} \mathrm{O}_{2}$ can be neglected and the eq. 5 and consequent reactions to form $\mathrm{OH}^{*}$ radicals (eqs. 6-7) are considered.

$$
\begin{array}{ll}
\mathrm{H}_{2} \mathrm{O}_{2} \leftrightarrow \mathrm{H}^{+}+\mathrm{HO}_{2}^{-} & \mathrm{K}_{\mathrm{a}}=2.24^{*} 10^{-12} \\
\mathrm{HO}_{2}^{-}+\mathrm{O}_{3} \rightarrow \mathrm{O}_{3}^{-}+\mathrm{HO}_{2}{ }^{-} & \mathrm{k}_{1}=(2.8 \pm 0.5) 10^{6} \mathrm{M}^{-1} \mathrm{~s}^{-1}\left(25^{\circ} \mathrm{C}\right) \\
\mathrm{O}_{3}{ }^{-}+\mathrm{H}^{+} \rightarrow \mathrm{OH}+\mathrm{O}_{2} & \\
\mathrm{HO}_{2}{ }^{-}+\mathrm{O}_{3} \rightarrow \mathrm{OH}^{-}+2 \mathrm{O}_{2} &
\end{array}
$$

Because the reaction with $\mathrm{OH}^{\bullet}$ radicals occurs much faster than that of $\mathrm{O}_{3}$, the reaction with ozone is ignored for total reaction rate [13].

Although there exist intensive literature on $\mathrm{O}_{3}$ oxidation of textile wastewater notated above, the toxicity removal by pre-ozonation, in particular, with the addition of $\mathrm{H}_{2} \mathrm{O}_{2}$ or $\mathrm{pH}$ varying has not been optimized due to wastewater characteristics in detail. In this study, pre-ozonation was attempted for detoxicifying, decolourizing and biodegradation of a textile finishing industry wastewater (Istanbul, Turkey). The effect of $\mathrm{pH}$ and $\mathrm{H}_{2} \mathrm{O}_{2}$ on ozone oxidation to remove toxicity was also investigated. $D$. magna as a standard and reliable toxicity testing method was used to optimize $\mathrm{O}_{3}$ dose $[4-6,8,16,19]$.

\section{MATERIALS AND METHODS}

\subsection{Sampling}

Raw textile wastewater sample was taken from the process wastewater balancing tank of a textile industry in which cotton and polyester fabrics are dyed using reactive, dispersive dyes. The wastewater is originated from bleaching and dyeing processes. Total process wastewater originated from the industry is around $500 \mathrm{~m}^{3}$ a day. The sample was delivered to the laboratory cooled and kept at $4{ }^{\circ} \mathrm{C}$ during experimental study. Toxicity tests were done within 1 day while chemical analyses were realized in 3 days after collection.

\subsection{Ozonation $\left(\mathrm{O}_{3}\right)$}

$\mathrm{O}_{3}$ was supplied by an air-ozone generator through a closed cylindrical pyrex glass reactor with a with a diameter of $40 \mathrm{~mm}$ and height of $1100 \mathrm{~mm}$. A tubular cylindrical porous diffuser was replaced at the bottom of the reactor to transfer input $\mathrm{O}_{3}$ gas into aqueous solution. Teflon tubing line was used for the connection between generator and the reactor (Figure 1). The appropriate $\mathrm{O}_{3}$ concentrations were adjusted by changing the electrical current of the ozone generator. All experiments were performed at room temperature $\left(25^{\circ} \mathrm{C}\right)$ and at original $\mathrm{pH}$ of wastewater. After ozonation, the samples were aerated for 5 min to remove possible residual $\mathrm{O}_{3}$. The $\mathrm{O}_{3}$ concentrations in input and off-gas were destroyed by two sequential washing bottles containing $250 \mathrm{ml}$ of acidified $2 \% \mathrm{KI}$ solution. Than, a sodium thyosulfite titration procedure in the presence of starch as the indicator was performed to measure $\mathrm{O}_{3}$ concentration $[20,21]$. The transfered $\mathrm{O}_{3}\left(\mathrm{TrO}_{3}\right)$ was calculated as the following:

$\mathrm{TrO}_{3}\left(\mathrm{mg} \mathrm{I}^{-1}\right)=$ input $\mathrm{O}_{3}$ concentration- $\mathrm{O}_{3}$ concentration in off gas

To avoid from the dilution errors during kinetics experiments, ozonation experiment repeated at time intervals under same conditions. The supernatants of the reactors were filtered 
through $0.45 \mu \mathrm{m}$ Millipore micro filter for COD, colour, absorbance and toxicity measurement. A low ozone dose (9.6 $\left.\mathrm{mg} \mathrm{min}^{-1}\right)$ was applied differing from the previous studies [8].

To evaluate the effect of $\mathrm{pH}$ which play important role in the process efficiency, in other terms, on the reaction kinetics [11,13], the original $\mathrm{pH}$ of wastewater adjusted to 5,9 and $11.0 \mathrm{pH}$ values and ozonated at the above described conditions for $10 \mathrm{~min}$. Further, the effect of $\mathrm{H}_{2} \mathrm{O}_{2}$ addition to $\mathrm{O}_{3}$ oxidation was investigated by adding $600 \mathrm{mg} \mathrm{I}^{-1}$ of $\mathrm{H}_{2} \mathrm{O}_{2}$ at original wastewater $\mathrm{pH}$ and the raw wastewater was ozonated for $20 \mathrm{~min}$ with the same $\mathrm{O}_{3}$ flow rate.

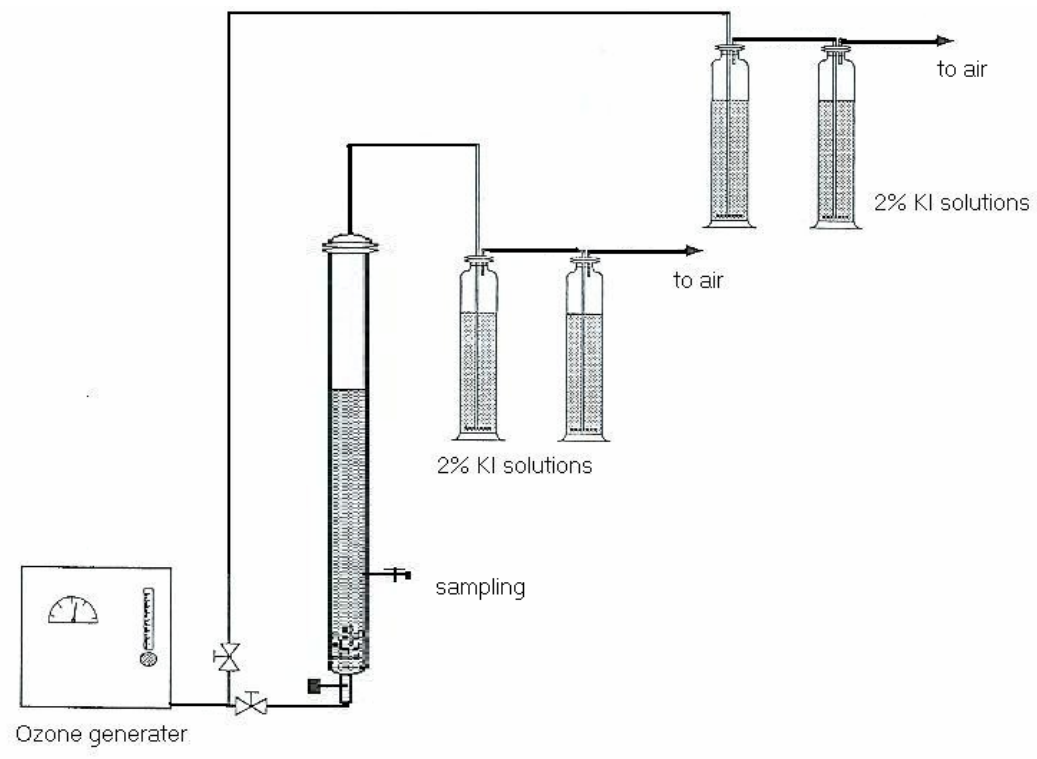

Figure 1. Ozonation set-up

\subsection{Daphnia magna}

The toxicity was measured using $24 \mathrm{~h}$ newborn $D$. magna at $50 \%$ dilution [22]. Raw and ozone pre-treated samples were tested within $2 \mathrm{~h}$ to avoid any effect of residual $\mathrm{O}_{3}$ [23]. Daphnids were grown in the laboratory at $16 \mathrm{~h}$ day light and $8 \mathrm{~h}$ dark periods supplying a 3000 lux illumination $[4,5,8]$. They were fed with Selenastrum capricornutum $\left(300.000 \mathrm{cell} \mathrm{ml}^{-1}\right)$ and baker's yeast (Schizosaccharomyces cerevisiae, 200.000 cells ml ${ }^{-1}$ ). Room temperature was kept at $20^{\circ} \mathrm{C} \pm 1^{\circ} \mathrm{C}$ and a minimum $6 \mathrm{mg} \mathrm{l}^{-1}$ of dissolved oxygen was supplied by air filtered through activated carbon. Experiments were carried out quadruplicate and 5 daphnids being used in each test beaker with $50 \mathrm{ml}$ of effective volume. All solutions were prepared using bidistilled water at $\mathrm{pH}$ 8.0. Results were expressed as a percentage of immobilised animals after $24 \mathrm{~h}$.

\subsection{Analysis}

COD was measured according to ISO6060 [24]. All other chemical parameters were measured according to Standard Methods [21]. Absorbance measurements were made using $1 \mathrm{~cm}$ cyristal cuvette in Pharmacia LKB-Novaspe II model spectrophotometer. HACH-Dr-B model spectrophotometer was used for colour measurements in Pt-Co unit. All chemicals used were of analytical grade. KI solution used for residual ozone titration was prepared daily.

\section{RESULTS AND DISCUSSION}

\subsection{General}

The characteristics of the raw wastewater are given in Table 1 . The ammonia concentration was higher than $25 \mathrm{mg} \mathrm{l}^{-1}$, was recorded $50 \%$ toxic to $D$. magna [25] for testing samples without dilutions. However, the raw water displayed $100 \%$ toxicity even at $50 \%$ dilution when the conductivity [6] and ammonia parameters were below the toxic limits. Therefore, the preozone oxidation was considered to remove the toxic component such as dyes, were toxic on D. magna [4,5] or auxilaries, found toxic on Vibrio fisheri [7]. 
Table 1. Raw wastewater characteristics

\begin{tabular}{|c|c|c|c|}
\hline \multicolumn{2}{|l|}{ Parameter } & Unit & Value \\
\hline \multicolumn{2}{|l|}{ Total COD } & $\mathrm{mg} \mathrm{l}^{-1}$ & 1200 \\
\hline \multicolumn{2}{|l|}{ Soluble COD } & $\mathrm{mg} \mathrm{l}^{-1}$ & 700 \\
\hline \multicolumn{2}{|l|}{ TSS } & $\mathrm{mg} \mathrm{l}^{-1}$ & 250 \\
\hline \multicolumn{2}{|l|}{ TKN } & $\mathrm{mg} \mathrm{l}^{-1}$ & 33 \\
\hline \multicolumn{2}{|l|}{$\mathrm{NH}_{3}-\mathrm{N}$} & $\mathrm{mg} \mathrm{l}^{-1}$ & 5 \\
\hline \multicolumn{2}{|l|}{ Total-P } & $\mathrm{mg} \mathrm{l}^{-1}$ & 2 \\
\hline \multicolumn{2}{|l|}{ Conductivity } & $\mathrm{mS} \mathrm{cm}^{-1}$ & 10000 \\
\hline \multicolumn{2}{|l|}{ Chloride } & $\mathrm{mg} \mathrm{l}^{-1}$ & 1600 \\
\hline \multicolumn{2}{|l|}{ Sulphate } & $\mathrm{mg} \mathrm{I}^{-1}$ & 590 \\
\hline \multirow{2}{*}{\multicolumn{2}{|c|}{ Colour }} & Pt-Co unit & 1060 \\
\hline & $450 \mathrm{~nm}$ & $\left(m^{-1}\right)$ & 0.397 \\
\hline \multirow{2}{*}{ Absorbance } & $500 \mathrm{~nm}$ & $\left(\mathrm{~m}^{-1}\right)$ & 0.469 \\
\hline & $550 \mathrm{~nm}$ & $\left(m^{-1}\right)$ & 0,415 \\
\hline \multicolumn{2}{|l|}{$\mathrm{pH}$} & -- & 7.8 \\
\hline \multicolumn{2}{|c|}{ Immobilization at $50 \%$ dilution } & $\%$ & 100 \\
\hline
\end{tabular}

\subsection{Ozone treatment and toxicity removal}

As seen in Figure $1 \mathrm{a}, \mathrm{TrO}_{3}$ dose increased linearly during first $10 \mathrm{~min}$ and it was almost stable between 15 and 20 min than it continued to increase gradually up to $45 \mathrm{~min}$. A cumulative $\mathrm{TrO}_{3}$ concentration was found to be $140.6 \mathrm{mg} \mathrm{l}^{-1}$ at the end of $45 \mathrm{~min} . \mathrm{TrO}_{3}$ rate was $9.5 \mathrm{mg} \mathrm{l}^{-1}$ $\mathrm{min}^{-1}$ during first minutes tahn it decreased gradually up to $3.8 \mathrm{mg} \mathrm{l}^{-1} \mathrm{~min}^{-1}$ at the end of 20 $\min$ and to $3.125 \mathrm{mg} \mathrm{l}^{-1} \mathrm{~min}^{-1}$ at the end of the reaction (Figure 1b). Absorbances at 450, 500 and $550 \mathrm{~nm}$ were removed at a range of $90-95 \%$ during 25 min when $82.5 \mathrm{mg} \mathrm{I}^{-1}$ of ozone concentration was transferred. Absorbance removals at 450, 500 and $550 \mathrm{~nm}$ obeyed first order kinetic as seen in Figure 2. Absorbance removal rates (k) are given in Table 2.

Table 2. Absorbance kinetics for pre-ozonation

\begin{tabular}{lccc}
\hline & $450 \mathrm{~nm}$ & $500 \mathrm{~nm}$ & $550 \mathrm{~nm}$ \\
\hline $\mathrm{k}\left(\mathrm{min}^{-1}\right)$ & 0.103 & 0.158 & 0.206 \\
$\mathrm{R}^{2}$ & 0.94 & 0.92 & 0.81 \\
\hline
\end{tabular}

Figure 3 illustrates the removal of soluble COD, colour (Pt-Co) and toxicity tested at $50 \%$ dilution of pre-ozonated wastewater. More than $90 \%$ of colour was removed during 10 min by $90 \mathrm{mg} \mathrm{l}^{-1}$ of $\mathrm{TrO}_{3}$. Soluble COD removal fluctuated during oxidation. While a $40 \%$ of soluble COD removed during first 2.5 than it decreased to $5 \%$ at the end of $15 \mathrm{~min}$. It increased again to $40 \%$ after $45 \mathrm{~min}$. This fluctuation was observed in the previous study [16]. This phenomenon was attributed to rapid oxidation of suspended solids which contributed to the soluble COD by time. However, a gradual increase in toxicity removal was observed. Toxicity removal $(60 \%)$ was lesser than color removal up to $25-30$ min but i increased to $100 \%$ by soluble COD removal increase at the end of $35 \mathrm{~min}$. This can be explained because the chromophor groups in textile dyes causing the effluent colour can be broken by ozone (directly or indirectly), forming smaller molecules resulting in colourless effluent [11] but the by-products which may be still toxic [8]. 

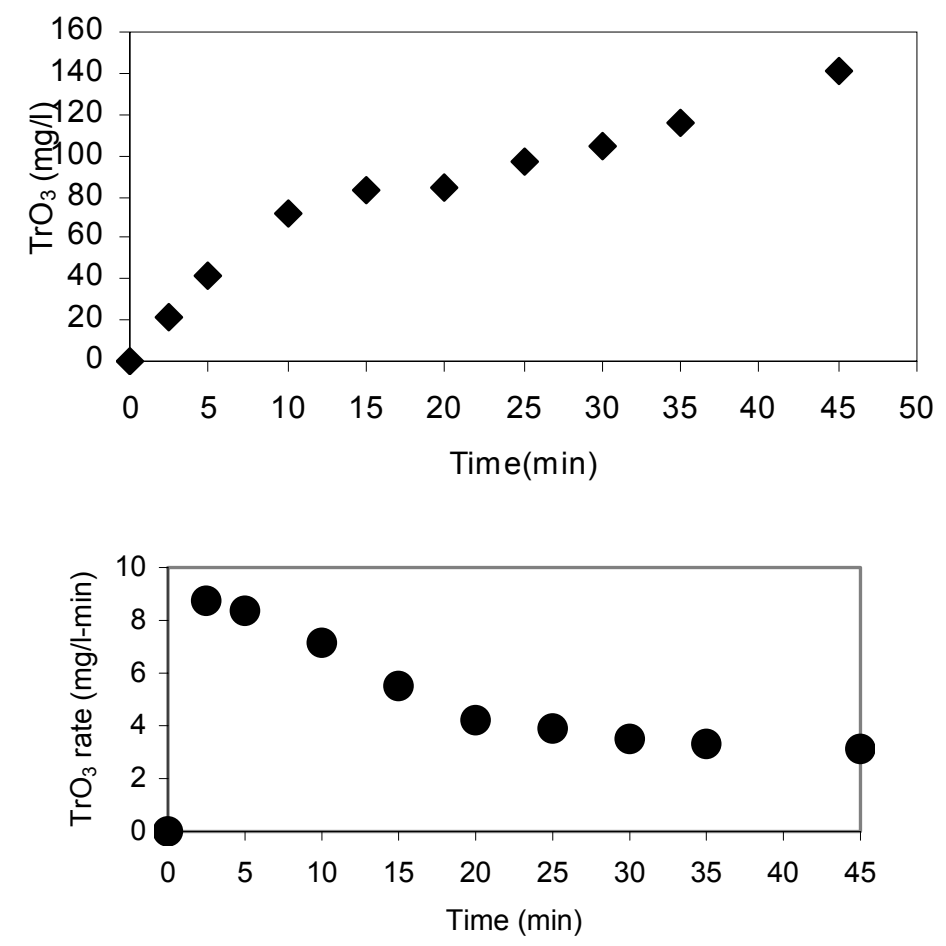

Figure 1. Transfered ozone dose (a) and transfered ozone rate (b).

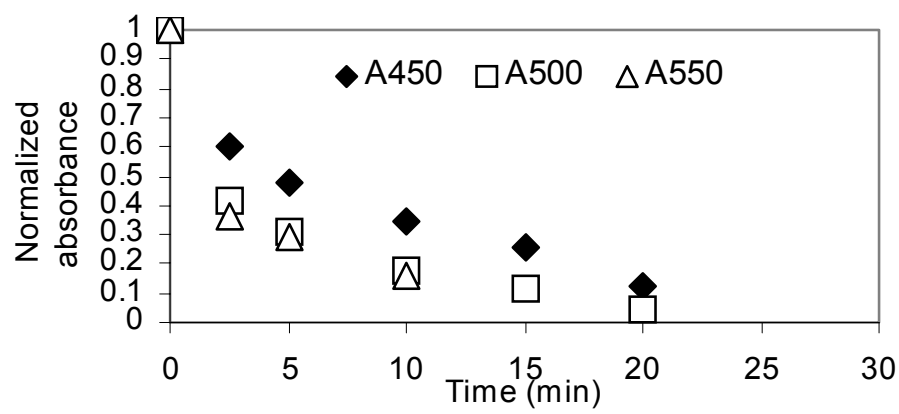

Figure 2. Normalized absorbance curves

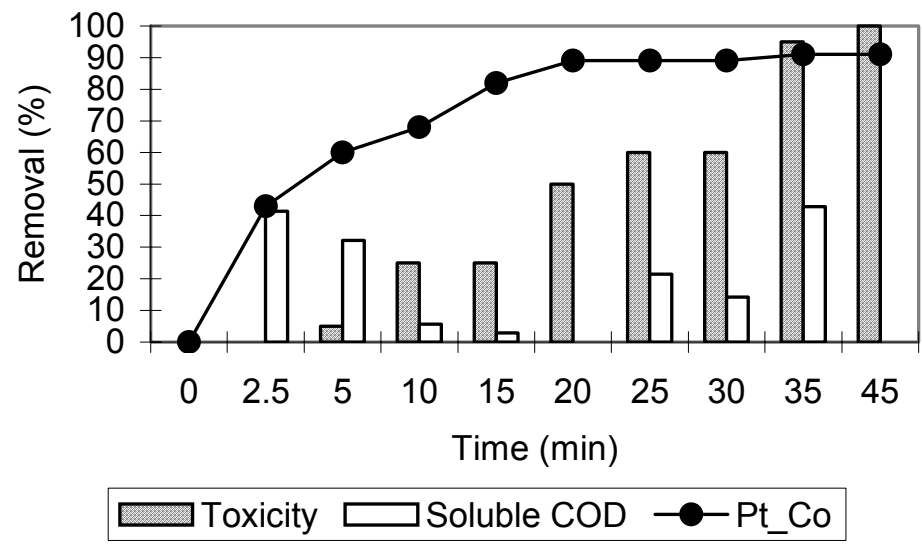

Figure 3. Colour, soluble $\mathrm{COD}$ and toxicity reduction during $\mathrm{O}_{3}$ oxidation 
According to equations 5-7, the addition of $\mathrm{H}_{2} \mathrm{O}_{2}$ was expected to increase the removal of toxicity, COD and colour. However, toxicity removal did not improve during $20 \mathrm{~min}$ of ozonation at original $\mathrm{pH}$ of wastewater. On the other hand, there was a slight (from $6 \%$ to $7.1 \%$ ) and significant (from 0 to 10\%) COD removal improvement at the end of 10 and 20 min respectively. A higher colour removal was recorded starting from $5 \mathrm{~min}(66 \%)$ and it reached $89 \%$ at the end of 15 min where toxicity was also removed higher than that of $\mathrm{O}_{3}$ oxidation alone. This result evidenced the relation between colour and toxicity removal [8] which seemed slightly related to COD [18]. Meanwhile, according to $\mathrm{O}_{3}$ oxidation alone, there was significant improvement in absorbance removals (Figure 4). First order absorbance degradation kinetic constants at 450, 500 and $550 \mathrm{~nm}$ are shown in Table 3.

$\mathrm{OH}$ radical is the most powerful oxidant and its formation in the $\mathrm{O}_{3} / \mathrm{H}_{2} \mathrm{O}_{2}$ system is much more faster than $\mathrm{O}_{3}$ treatment. However, the $\mathrm{pH}$ affects the decomposition of $\mathrm{H}_{2} \mathrm{O}_{2}$ in the solution. Therefore, the optimization of the $\mathrm{pH}$ and the ratio of $\mathrm{O}_{3}: \mathrm{H}_{2} \mathrm{O}_{2}$ dose should be detailed further. Besides, the applied $\mathrm{O}_{3}$ dose as well as the oxidation time should be optimized to evaluate its contribution to toxicity removal, instead causing any toxicity increase in the effluent $[5,12]$.
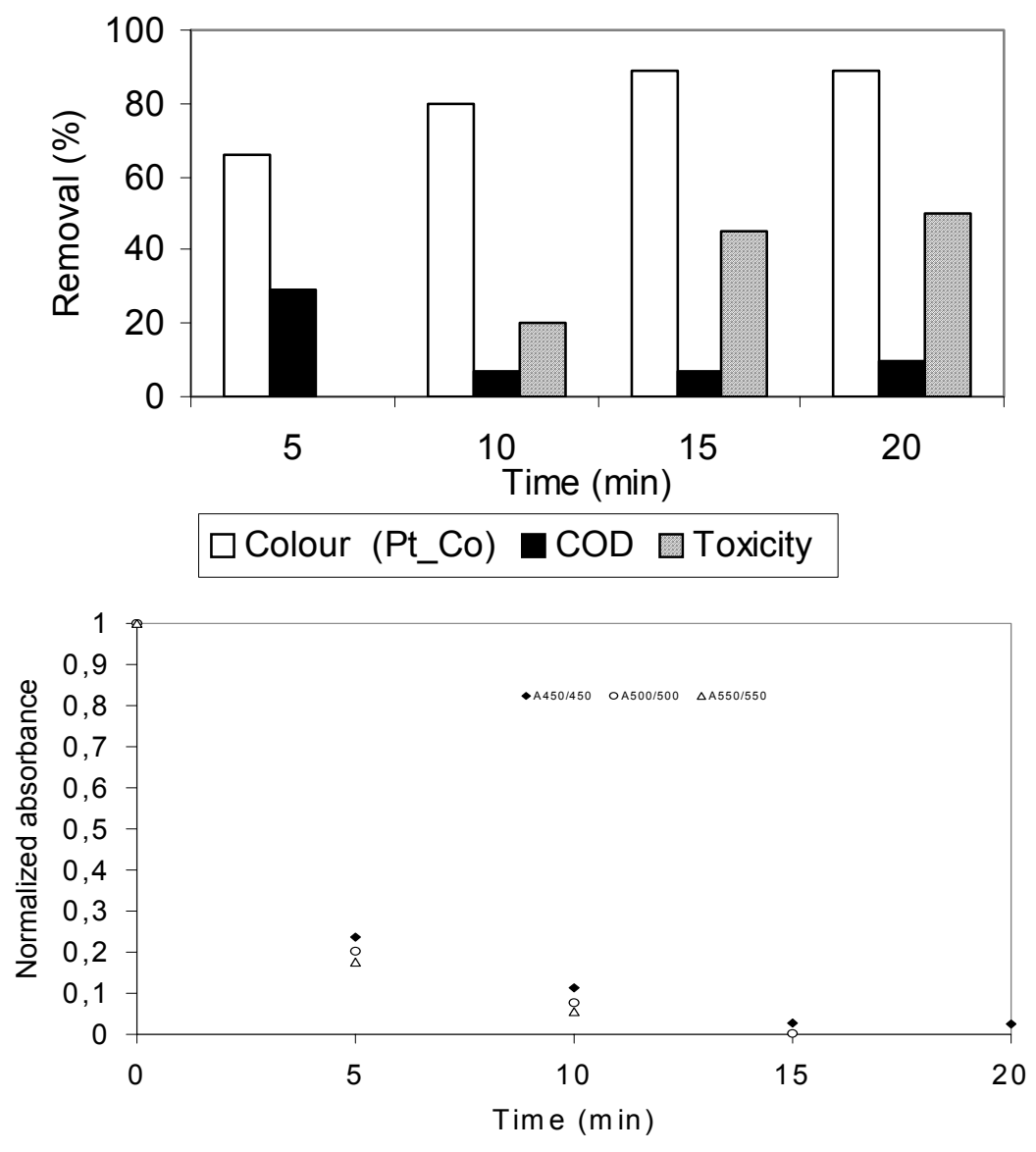

Figure 4. The effect of $\mathrm{H}_{2} \mathrm{O}_{2}$ addition on ozone oxidation at original wastewater $\mathrm{pH}$ (a-removal of colour, soluble COD and toxicity, b-absorbance)

Table 3. Absorbance kinetics for $\mathrm{O}_{3} / \mathrm{H}_{2} \mathrm{O}_{2}$ oxidation for 20 min

\begin{tabular}{lccc}
\hline & $450 \mathrm{~nm}$ & $500 \mathrm{~nm}$ & $550 \mathrm{~nm}$ \\
\hline $\mathrm{k}\left(\mathrm{min}^{-1}\right)$ & 0.206 & 0.3598 & 0.301 \\
$\mathrm{R}^{2}$ & 0.94 & 0.92 & 0.98 \\
\hline
\end{tabular}

10 min ozonation at 5,9 and $11.0 \mathrm{pH}$ values did not improve the toxicity removal $(0 \%$ at all $\mathrm{pH}$ values) as shown in Figure 5. The soluble COD removal was improved at $3 \%$ and $6 \%$ at 9.0 and $11.0 \mathrm{pH}$ values, respectively with respect to $\mathrm{O}_{3}$ oxidation alone. Because $\mathrm{O}_{3}$ decomposes readily to $\mathrm{OH}^{\bullet}$ radicals at high $\mathrm{pH}(11.0-12.0)$ which are much more powerful than molecular 
$\mathrm{O}_{3}$, thus it favours higher TOC removal due to ozonation time [13]. However, no significant increase in this study can be attributed to the presence of $\mathrm{Na}_{2} \mathrm{CO}_{3}$, a considerable amount of $\mathrm{OH}^{\bullet}$ radicals will be scavenged by $\mathrm{CO}_{3}{ }^{2-}$ thus wasting $\mathrm{OH}^{\cdot}$ oxidant [13]On the other hand, lesser colour removal was obtained at 5.0 and $9.0 \mathrm{pH}$ values $(48 \%$ and $60 \%$ respectively) while the colour removal was the same at $11.0 \mathrm{pH}$.

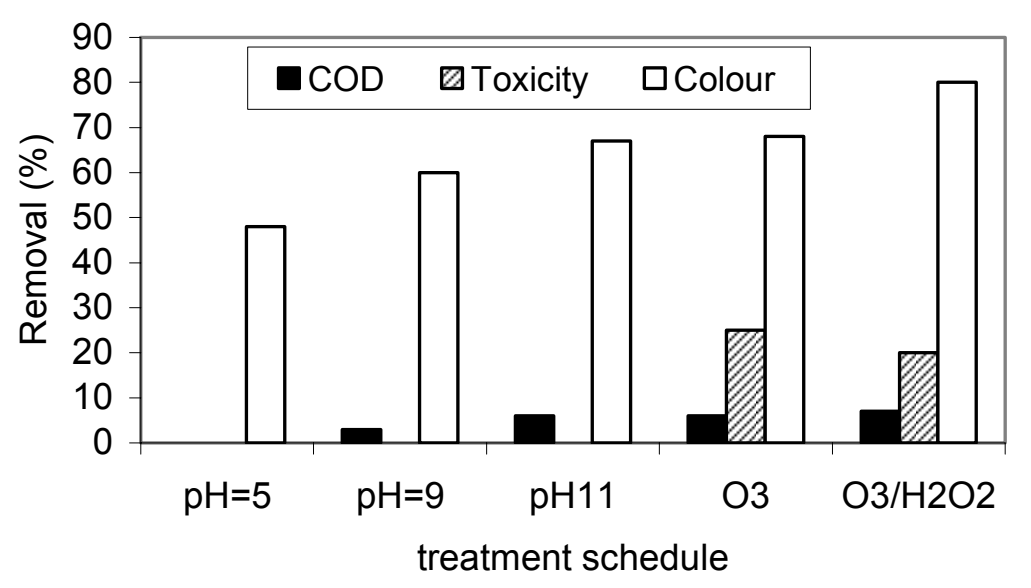

Figure 5. Comparison of colour, soluble COD and toxicity removal versus treatment

\section{CONCLUSIONS}

This study aimed to evaluate pre-ozonation at a low ozone dose for removal of acute toxicity as well as colour and COD in a textile industry wastewater. The effect of $\mathrm{pH}$ varying from 5 to 11 and the $\mathrm{H}_{2} \mathrm{O}_{2}$ dose of $600 \mathrm{mg} \mathrm{l}^{-1}$ on ozone oxidation were also investigated. Acute toxicity of raw and treated samples was monitored using $24 \mathrm{~h}$ new born Daphnia magna according to standard procedure.

- By applying $9.5 \mathrm{mg} \mathrm{min}^{-1}$ ozone dose rate for $20 \mathrm{~min} 60 \%$ toxicity removal was obtained at $50 \%$ dilution when $>85 \%$ colour ( $\mathrm{Pt}-\mathrm{Co}$ ) and $>90 \%$ of absorbance removals were also achieved.

- To obtain $50 \%$ toxicity removal corresponding $50 \%$ removal when the sample will not diluted the sample had to be ozonated for $35 \mathrm{~min}$ when also $>30 \%$ soluble COD was recorded.

- The fluctuation in COD removal was related to the rapid oxidation of suspended solids resulting in increased soluble COD.

- The composition of wastewater which is also related to the intensity of the colour, was related to the acute toxicity of the wastewater.

- Varying pH form 5 to 11 did not improve the toxicity neither colour removal.

- Addition of $\mathrm{H}_{2} \mathrm{O}_{2}$ increased the colour as well as absorbance removal.

The results obtained this study are expected to contribute to control the textile industry wastewater pollution and to protect aquatic environment. However, there is still need some further studies to optimize $\mathrm{O}_{3}$ dose, and ratio of $\mathrm{O}_{3} / \mathrm{H}_{2} \mathrm{O}_{2}$. Besides, these kind of studies are recommended to be supported by chronic toxicity experiments to improve the discharge standards.

\section{ACKNOWLEGMENTS}

This work was partly supported by Scientific Research Council of Turkey (IÇTAG-Ç035). The technical support by Volkan Enç and kind collaboration by the industry are greately appreciated.

\section{REFERENCES}

1. Chung, K.T., Stevens, S.E.J., Cerniglia, C.E. (1992). The reduction of azo dyes by the intestinal microflora, Critical Review Microbiology, 18, 175-197.

2. Chung, K.T., Stevens, S.E.J. (1993) Degradation of azo dyes by environmental microorganisms and helmints, Environ. Toxicol. Chem., 12, 2121-2132. 
3. Gottlieb, A., Shaw, C., Smith, C., Wheatley, A., Forsythe, S. (2003) The toxicity of textile reactive azo dyes after hydrolysis and decolourisation, J. Biotechnol., 101, 49-56.

4. Meric, S., Kaptan, D., Olmez, T. (2004) Color and COD removal from wastewater containing reactive Black 5 using Fenton's oxidation process, Chemosphere, 54(3), 435-441.

5. Meric, S., Selcuk, H., Gallo, M., Belgiorno, V. (2005) Decolourisation and detoxicifying of Remazol Red dye and its mixture using Fenton's reagent, Desalination, 173 (3), 239-248.

6. Villegas-Navarro, A., Ramiez, M.Y., Salvador, M.S.B., Gallardo, Y.M. (2001) Determination of wastewater $\mathrm{LC}_{50}$ of the different process stages of the textile industry, Ecotoxicol. Environ. Saf., 48, 56-61.

7. Wang, C., Yediler, A., Lienert, D., Wang, Z., Kettrup, A. (2002) Toxicity evaluation of reactive dyestuff, auxiliaries and selected effluents in textile finishing industry to luminescent bacteria Vibrio fisheri, Chemosphere, 46, 339-344.

8. Meric, S., Selcuk, H., Belgiorno, V. (2005) Acute toxicity removal in textile finishing wastewater by Fenton's oxidation, ozone and coagulation-flocculation processes, Water Res., 39, 1147-1153.

9. De-Moraes, S.G., Freire, R.S., Duran, N. (2000) Degradation and toxicity reduction of textile effluent by combined photocatalytic and ozonation processes, Chemosphere, 40, 369-373.

10. Rodriguez, M., Sarria, V., Esplugas, S., Pulgarin, C. (2002) Photo-Fenton treatment of a biorecalcitrant wastewater generated in textile activities: biodegradability of the photo-treated solution, J Photochem. Photobiol. A: Chemistry, 151, 129-135.

11. Liakou S., Pavlou S., Lyberatos G. (1997) Ozonation of dyes, Water Sci. Tech., 35 (4), 279-286.

12. Ledakowicz, S., Solecka, M., Zylla, R. (2001) Biodegradation, decolourisation and detoxification of textile wastewater enhanced by advanced oxidation processes, J. Biotechnol., 89, 175-84.

13. Arslan Alaton, I., Akmehmet Balcioglu, I., Bahnemann, D.W. (2002) Advanced oxidation of reactive dyebath effluent: comparison of $\mathrm{O}_{3}, \mathrm{H}_{2} \mathrm{O}_{2} / \mathrm{UV}-\mathrm{C}$ and $\mathrm{TiO}_{2} / \mathrm{UV}-\mathrm{A}$ processes, Water Res., 36, 1143-1154.

14. Baban, A., Yediler, A., Lienert, D., Kemerdere, N., Kettrup, A. (2003) Ozonation of high strength segregated effluents from a woollen textile dyeing and finishing plant, Dyes and Pigments, 58, 93-98.

15. Karahan, O., Dulkadiroglu, H., Kabdasli, I., Sozen, S., Germirli Babuna, F., Orhon, D. (2002) Effect of ozonation on the biological treatability of a textile mill effluent, Envrion. Technol., 23, 1325-1336.

16. Selcuk, H. (2005) Decolourization and detoxicification of textile wastewater by ozonation and coagulation processes, Dyes and Pigments, 64, 217-222.

17. Lim, B.R., Hu, H.Y., Ahn, K.H., Fujie, K. (2004) Oxidative treatment characteristics of biotreated textile-dyeing wastewater and chemical agents used in a textile-dyeing process by advanced oxidation process. Water Science and Technology 49(5-6), 137-143.

18. Hoigne, J., Bader, H. (1983) Rate constants of reactions of ozone with organic and inorganic compounds in water-I, Water Res., 17, 185-194.

19. Fernandez-Alba, A.R., Hernando, D., Aguera, A., Caceres, J., Malato, S. (2002) Toxicity assays: a way for evaluating AOPs efficiency, Wat. Res., 36, 4255-4262.

20. IOA (1987) lodometric method for ozone measurement, Standardization Committe-Europe, 001/87 (F), Brussel.

21. APHA, AWWA, WEF (1998) Standard Methods for the Examination of Water and Wastewater, $20^{\text {th }}$ edition, American Public Health Association/American Water Works Association/Water Environment Federation, Washington DC, USA, 1998.

22. ISO (International Organisation for Standardisation, Geneva, Switzerland) (1996) Water Quality-Determination of The Inhibition of The Mobility of Daphnia magna Starus (cladocera, Crustacea)- Acute Toxicity Test, ISO 66431, Geneva.

23. Leynen, M., Duvivier, L., Girboux, P., Ollevier, F. (1998) Toxicity of ozone to fish larvae and Daphnia magna, Ecotoxicol. Environ. Saf., 41, 176-79.

24. ISO (International Organisation for Standardisation, Geneva, Switzerland) (1986) Water Quality-Determination of The Chemical Oxygen Demand, ISO6060, Geneva.

25. Marttinen, S.K., Kettunen, R.H., Sormunen, K.M., Soimasuo, R.M., Rintala, J.A. (2002) Screening of physical-chemical methods for removal of organic material, nitrogen and toxicity from low strength landfill leachates, Chemosphere, 46, 851-858. 